\title{
Pertanggungjawaban Pejabat Pemerintahan dalam Menetapkan Diskresi (Studi terhadap Putusan Mahkamah Konstitusi Nomor 25/PUU-XIV/2016)
}

\author{
Zaki Ulya \\ Fakultas Hukum Universitas Samudra \\ Jln. Meurandeh, Kecamatan Langsa Lama, Kota Langsa-Aceh \\ zaki.ulya@gmail.com
}

Received: 4 Juni 2017; Accepted: 13 September 2017; Published: 28 Februari 2018

DOI: 10.20885/iustum.vol24.iss3.art4

\begin{abstract}
Decision of the Constitutional Court Number 25/PUU-XIV/2016 has given authority to government officials in exercising discretion related to the use of both state budget and regional budget. The problems in this study were: how is the pattern of liability of the government officials who have exercised discretion and how are the efforts and limitations in exercising a discretion by government officials to avoid corruption. This was a normative legal research, using statute and concept approach. The results concluded that Decision of the Constitutional Court Number 25/ PUU-XIV/2016 has revoked the provisions in Article 2 Paragraph (1) and Article 3 of Corruption Law by stating to be contradictory to the constitution. Nevertheless, the liability for the discretion exercised by government officials shall be done in accordance with the general principles of good governance and Law No. 30 of 2014 and Law No. 17 of 2003. The limitation for government officials in exercising discretion, especially after the issuance of the Decision of Constitutional Court, is to conform to the provisions of legislation.
\end{abstract}

Keywords: Liability; Government Officials; Discretion

\section{Abstrak}

Putusan MK Nomor 25/PUU-XIV/2016 telah memberikan keleluasan bagi pejabat pemerintahan dalam menerbitkan diskresi terkait penggunaan anggaran negara maupun daerah. Permasalahan dalam penelitian ini, bagaimana pola pertanggungjawaban pejabat pemerintahan yang telah menerbitkan diskresi serta upaya dan batasan dalam menerbitkan suatu diskresi oleh pejabat pemerintahan agar terhindar dari tindak pidana korupsi. Kajian ini menggunakan metode penelitian hukum normatif, dengan menggunakan pendekatan perundang-undangan dan konsep. Hasil kajian menyimpulkan bahwa Putusan MK Nomor 25/PUU-XIV/2016 telah membatalkan ketentuan Pasal 2 Ayat (1) dan Pasal 3 UU Tipikor dengan menyatakan bertentangan dengan konstitusi. Namun dalam hal pertanggungjawaban diskresi yang dikeluarkan oleh pejabat pemerintahan tetap wajib dilakukan sesuai dengan asas-asas umum pemerintahan yang baik dan Undang-Undang No. 30 Tahun 2014 dan Undang-Undang No. 17 Tahun 2003. Batasan bagi pejabat pemerintahan dalam menerbitkan diskresi khususnya pasca Putusan MK yaitu dengan ketaatasasan pada ketentuan peraturan perundang-undangan.

Kata-kata Kunci: Pertanggungjawaban; Pejabat Pemerintahan; Diskresi 


\section{Pendahuluan}

Pada prinsipnya setiap pejabat negara memiliki kewenangan dalam menetapkan suatu kebijakan, baik kebijakan berdasarkan amanah peraturan perundang-undangan maupun akibat ketiadaan hukum yang mengatur. Pejabat negara yang memegang jabatan tertentu baik dalam bidang eksekutif, legislatif dan yudikatif membuat suatu kebijakan publik untuk mencapai tujuan tertentu, dan umumnya dilalui beberapa tahapan. Kebijakan publik akan dilaksanakan oleh administrasi negara yang dijalankan oleh birokrasi pemerintah. Fokus utama dari kebijakan publik dalam negara modern yaitu pelayanan publik, yang merupakan segala sesuatu yang dapat dilakukan oleh negara untuk mempertahankan atau meningkatkan kualitas kehidupan orang-orang banyak. ${ }^{1}$

Kebijakan yang dapat ditentukan oleh pejabat pemerintah salah satunya adalah kebijakan yang ditetapkan pada suatu waktu dibutuhkan legalitasnya. Kebijakan tersebut umumnya diambil oleh pejabat pemerintah dalam bentuk diskresi. Secara sederhana, pengertian diskresi menurut Kamus Besar Bahasa Indonesia mengartikan sebagai kebebasan mengambil keputusan sendiri dalam setiap situasi yang dihadapi. ${ }^{2}$

Sementara itu, menurut Kamus Hukum terbitan Badan Pembinaan Hukum Nasional mendefinisikannya diskresi sebagai kekuasaan bertindak dari pejabat pemerintah dalam situasi tertentu berdasarkan keyakinannya yang mengarah pada kebaikan, keadilan, dan kelayakan. ${ }^{3}$ Pasal 1 angka 9 UU Nomor 30 Tahun 2014 tentang Administrasi Pemerintahan menjelaskan diskresi adalah keputusan dan/atau tindakan yang ditetapkan dan/atau dilakukan oleh Pejabat Pemerintahan untuk mengatasi persoalan konkret yang dihadapi dalam penyelenggaraan pemerintahan dalam hal peraturan perundang-undangan yang memberikan pilihan, tidak mengatur, tidak lengkap atau tidak jelas, dan/atau adanya stagnasi pemerintahan.

Akibat luasnya pengambilan kebijakan yang dilakukan oleh pejabat pemerintah tersebut maka tentunya diharuskan diimbangi dengan adanya

\footnotetext{
${ }^{1}$ James E. Anderson, Public Policy Making, cet. ke-3, Holt, Rinehart and Winston, New York, 1984, hlm. 12

2 Anonimous, Kamus Besar Babasa Indonesia, Pusat Bahasa Departemen Pendidikan Nasional, Jakarta, 2008, hlm. 199

3 Anonimous, Penyusunan Kamus Hukum Umum Babasa Belanda-Bahasa Indonesia, BPHN Departemen Kehakiman, Jakarta, 1999, hlm. 68
} 
perlindungan hukum terhadap pengambil kebijakan, di mana seyogyanya setiap kebijakan yang telah disahkan wajib dipertanggungjawabkan. Dan pertanggungjawaban yang dimaksud salah satunya merupakan bentuk laporan kepada atasan dalam waktu tertentu.

Apabila dikaji regulasi yang telah disebutkan di atas, frasa "atau orang lain atau suatu korporasi" dalam Pasal 2 ayat (1) dan Pasal 3 UU No. 31 Tahun 1999, sangat merugikan pejabat pemerintahan dalam menjalankan tugas dan kewenangannya baik tingkat pemerintahan pusat ataupun daerah. Sebab, dalam menjalankan tugasnya, setiap pejabat pemerintahan tidak dapat menghindari tindakan mengeluarkan keputusan tertentu, khususnya dalam hal penentuan pelaksana proyek pemerintahan yang dipastikan menguntungkan orang lain atau suatu korporasi. Khususnya juga dalam hal penetapan suatu diskresi sebagaimana disebutkan dalam frasa “...menyalahgunakan kewenangan, kesempatan atau sarana yang ada padanya karena jabatan atau kedudukan yang dapat merugikan keuangan Negara...". Frasa "karena jabatan atau kedudukan" tentunya sudah termasuk dalam hal penetapan suatu diskresi yang dilakukan oleh pejabat pemerintahan.

Meningkatnya kekhawatiran pejabat pemerintah dalam menentukan kebijakan (diskresi) yang mengakibatkan dapat diduga melakukan tindak pidana korupsi pasca diterbitkannya diskresi telah diputuskan oleh Mahkamah Konstitusi yaitu dalam Putusan Mahkamah Konstitusi No. 25/PUU-XIV/2016 tentang pengujian Pasal 2 ayat (1) dan Pasal 3 UU Tipikor. Amar putusannya menyebutkan bahwa ketentuan Pasal 2 ayat (1) dan Pasal 3 Undang-Undang No. 31 Tahun 1999 dan Undang-Undang No. 20 Tahun 2001 sepanjang frasa "dapat" bertentangan dengan konstitusi dan menolak permohonan sebagian. ${ }^{4}$

Menurut Anwar Usman, kriminalisasi kebijakan terjadi karena terdapat perbedaan pemaknaan kata "dapat" dalam unsur merugikan keuangan negara dalam tindak pidana korupsi oleh aparat penegak hukum. Untuk itu, menurut Mahkamah Konstitusi dalam pertimbangan hukumnya pencantuman kata "dapat" dalam Pasal 2 ayat (1) dan Pasal 3 UU Tipikor menimbulkan ketidakpastian hukum dan telah secara nyata bertentangan dengan jaminan bahwa setiap orang berhak

${ }^{4}$ Lihat dalam Putusan Mahkamah Konstitusi No. 25/PUU-XIV/2016, hlm. 1-2 
atas rasa aman dan perlindungan dari ancaman ketakutan sebagaimana ditentukan dalam Pasal 28G ayat (1) UUD $1945 .^{5}$

Sebagaimana data yang dipaparkan oleh KPK menunjukkan bahwa setidaknya 332 pejabat publik terjerat kasus korupsi dan kerugian yang diderita negara mencapai Rp. 39.300.000.000.000,00.6 Merujuk pada data tersebut juga menunjukkan bahwa penerapan diskresi yang ditetapkan oleh pejabat pemerintahan masih dinilai "rawan", khususnya terkait pendayagunaan anggaran negara maupun daerah.

Menyimak amar putusan Mahkamah Konstitusi, seyogyanya setiap pejabat pemerintah dalam menerbitkan suatu diskresi tentunya tidak ada permasalahan lagi. Dampak hukum dalam praktik ke depannya adalah aparatur penegak hukum harus dapat membuktikan adanya kerugian negara yang riil sebelum melakukan penyelidikan perkara korupsi.

\section{Rumusan Masalah}

Adapun rumusan masalah dalam kajian ini di antaranya: Pertama, bagaimanakah pola pertanggungjawaban yang harus dilakukan pejabat pemerintahan setelah menetapkan diskresi? Kedua, bagaimana batasan dan upaya pencegahan yang harus dilakukan oleh pejabat pemerintahan dalam menerbitkan diskresi agar terhindar dari tindak pidana korupsi?

\section{Tujuan Penelitian}

Tujuan kajian ini yaitu untuk mengkaji dan menganalisis pola pertanggungjawaban yang harus dilakukan pejabat pemerintahan setelah menetapkan diskresi. Untuk mengkaji dan menganalisis batasan dan upaya pencegahan yang harus dilakukan oleh pejabat pemerintahan dalam menerbitkan diskresi agar terhindar dari tindak pidana korupsi.

\section{Metode Penelitian}

Penelitian ini merupakan penelitian hukum normatif yang menggunakan data sekunder yang terdiri dari bahan hukum primer yang mencakup dari buku

\footnotetext{
5 Anwar Usman dalam Laporan Utama, "Potensi Kriminalisasi, Kata "dapat" Dalam UU Tipikor Inkonstitutional”, Majalah Konstitusi No. 120, Edisi Februari 2017, hlm. 15

6 Anonim, “332 Pejabat Terjerat Korupsi, Negara Rugi Rp. 39.300.000.000.000,00”, http://kpk.go.id/id/ nukpk/id/berita/berita-sub/726-332-pejabat-terjerat-korupsi-negara-rugi-rp-39-3-triliun, diakses pada 13 Juni 2017
} 
terkait permasalahan dalam kajian ini, khususnya Putusan Mahkamah Konstitusi No. 25/PUU-XIV/2016. Bahan hukum sekunder yaitu jurnal, makalah dan kamus. Dan, bahan hukum tersier yang digunakan adalah bahan dan data dari internet. Pendekatan yang digunakan dalam penelitian ini adalah pendekatan perundangundangan (statute approach), dan pendekatan konsep (conceptual approach). Semua bahan hukum yang diperoleh dalam penelitian akan dikumpulkan, dikelompokkan sesuai variabel masing-masing, untuk selanjutnya dianalisis secara kualitatif. Hasil dari penelitian iniakan disajikan dalam bentuk deskriptif analitis. ${ }^{7}$

\section{Hasil Penelitian dan Pembahasan}

\section{Tinjauan Yuridis tentang Diskresi dan Wewenang Konsep Diskresi}

Diskresi diperlukan sebagai pelengkap asas legalitas, yaitu asas hukum yang menyatakan bahwa setiap tindak atau perbuatan administrasi negara harus berdasarkan ketentuan undang-undang, akan tetapi tidak mungkin bagi undangundang untuk mengatur segala macam hal dalam praktek kehidupan sehari-hari. ${ }^{8}$

Secara etimologi berasal dari dua kata freies dan Ermessen. Pengertian Freies Ermessen berasal dari kata frei dan freie yang berarti bebas, merdeka, tidak terikat, lepas dan orang bebas. Ermessen berarti mempertimbangkan, menilai, menduga, penilaian, pertimbangan dan keputusan. ${ }^{9}$ Sedang secara etimologis, freies Ermessen artinya orang yang bebas mempertimbangkan, bebas menilai, bebas menduga, dan bebas mengambil keputusan (Pouvoir Discretionare: Perancis, Discretionary Power: Inggris). ${ }^{10}$ Freies Ermessen berarti orang yang memiliki kebebasan untuk menilai, menduga, dan mempertimbangkan sesuatu. Sedangkan Nata Saputra mengartikan freies Ermessen sebagai suatu kebebasan yang diberikan kepada alat administrasi, yaitu kebebasan yang pada asasnya memperkenankan alat administrasi Negara

\footnotetext{
${ }^{7}$ Peter Mahmud Marzuki, Penelitian Hukum, Kencana Prenada Media Group, Jakarta, 2005, hlm. 93-95

8 Irfan M. Islamy, Prinsip-Prinsip Perumusan Kebijakan Negara, Cet. ke-15, Bumi Aksara, Jakarta, 2009, hlm. 31

9 Arfan Faiz Muhlizi, "Reformulasi Diskresi Dalam Penataan Hukum Administrasi", Jurnal Rechtsvinding, Vol. 1 No. 1, Januari-April 2012, hlm. 99

${ }_{10}$ S.F. Marbun, Peradilan Administrasi Negara dan Upaya Administratif di Indonesia, FH UII Press, Yogyakarta,
} 2011, hlm. 186 
mengutamakan keefektifan tercapainya suatu tujuan dari pada berpegang teguh kepada ketentuan hukum. ${ }^{11}$

Ada juga yang mengatakan bahwa freies Ermessen sama dengan diskresi, yaitu kebebasan untuk dapat bertindak atas inisiatif sendiri, terutama dalam menyelesaikan persoalan yang memerlukan penanganan segera tetapi peraturan untuk penyelesaian persoalan itu belum ada karena belum dibuat oleh badan yang diserahi tugas legislatif. ${ }^{12}$ Menurut Laica Marzuki dalam tulisan Julista Mustamu menyebutkan bahwa freies Ermessen merupakan kebebasan yang diberikan kepada tata usaha negara dalam rangka penyelenggaraan pemerintahan, sejalan dengan meningkatnya tuntutan pelayanan publik yang harus diberikan tata usaha Negara terhadap kehidupan sosial ekonomi para warga yang komplek. Secara umum freies Ermessen berarti orang bebas mempertimbangkan, bebas menilai, bebas menduga, dan bebas mengambil keputusan. ${ }^{13}$

Pouvoir Discretionare atau Freies Ermessen merupakan kemerdekaan bertindak atas inisiatif dan kebijakan sendiri dari administrasi negara pada welfare state. Fungsi publik service dalam penyelenggaraan pemerintahan welfare state mengakibatkan terjadinya pergeseran sebagian kekuasaan antar lembaga negara yaitu dari lembaga legislatif ke lembaga eksekutif (administrasi negara). ${ }^{14}$ Pengertian discretie dalam pourvoir discretionare adalah pejabat penguasa tidak boleh menolak mengambil keputusan dengan alasan "tidak ada peraturannya" dan oleh karena itu diberi kebebasan untuk mengambil keputusan menurut pendapat sendiri asalkan tidak melanggar asas yuriditas dan asas legalitas. ${ }^{15}$

Dalam ilmu Hukum Administrasi, freies Ermessen ini diberikan hanya kepada pemerintah, dan ketika freies Ermessen ini diwujudkan menjadi instrumen yuridis yang tertulis, maka jadilah sebagai peraturan kebijaksanaan. ${ }^{16}$ Di sisi lain, kebebasan bertindak oleh aparatur pemerintahan yang berwenang jika tidak

\footnotetext{
${ }^{11}$ Nata Saputra, Hukum Administrasi Negara, Rajawali, Jakarta, 1988, hlm. 15

12 Ibid., hlm. 16

${ }^{13}$ Julista Mustamu, "Diskresi Dan Tanggung Jawab Administrasi Pemerintahan”, Jurnal Sasi, Vol. 17, No. 2, April-Juni 2011, hlm. 4

${ }^{14}$ Ibid., hlm. 5

${ }^{15}$ Ridwan HR, Hukum Administrasi Negara, PT. Raja Grafindo Persada, Jakarta, 2007, hlm. 177

16 Suwoto Mulyosudarmo, Kekuasaan dan Tanggung Jawab Presiden Republik Indonesia, Suatu Penelitian Segi-Segi Teoritik dan Yuridis Pertanggungjawaban Kekuasaan, Universitas Airlangga, Surabaya, 1990, hlm. 30
} 
digunakan secara cermat dan hati-hati maka penerapan asas Freies Ermessen ini rawan menjadi konflik struktural yang berkepanjangan antara penguasa dengan masayarakat. Secara alamiah, terdapat perbedaan gerak antara pembuatan undang-undang dengan persoalan-persoalan yang berkembang di masyarakat.

Pembuatan undang-undang berjalan lambat, sementara persoalan kemasyarakatan berjalan dengan pesat. Jika setiap tindakan pemerintah harus selalu berdasarkan undang-undang, maka akan banyak persoalan kemasyarakatan yang tidak dapat terlayani secara wajar. Oleh karena itu, dalam konsepsi welfare state, tindakan pemerintah tidak selalu harus berdasarkan asas legalitas. ${ }^{17}$

Meskipun pemberian freies Ermessen atau kewenangan bebas (discresionare power) kepada pemerintah merupakan konsekuensi logis dalam konsepsi welfare state, akan tetapi pemberian freies Ermessen ini bukan tanpa masalah. Sebab adanya kewenangan bebas ini berarti terbuka peluang penyalahgunaan wewenang (detournement de pouvoir) atau tindakan sewenang-wenang (willekeur) yang dapat merugikan warga negara. Atas dasar ini penerapan fungsi Hukum Administrasi Negara (HAN) dalam konsepsi welfare state merupakan salah satu alternatif bagi penyelenggaraan pemerintahan yang bersih. ${ }^{18}$

Menurut Philipus M. Hadjon, HAN memiliki tiga fungsi yaitu fungsi normatif, fungsi instrumental, dan fungsi jaminan. Fungsi normatif menyangkut penormaan kekuasaan memerintah dalam upaya mewujudkan pemerintahan yang bersih. Fungsi instrumental berarti menetapkan instrumen yang digunakan oleh pemerintah untuk menggunakan kekuasaan memerintah. Adapun fungsi jaminan adalah fungsi untuk memberikan jaminan perlindungan hukum bagi rakyat. ${ }^{19}$

\section{Teori Kewenangan}

Wewenang (Authority) merupakan suatu wadah yang berfungsi sebagai penggerak dari pada kegiatan. ${ }^{20}$ Wewenang yang bersifat informal, untuk mendapatkan kerjasama yang baik dengan bawahan. Di samping itu, wewenang

${ }^{17}$ Ibid., hlm. 31

${ }^{18}$ Jazim Hamidi, Penerapan Asas-asas Umum Penyelenggaraan Pemerintahan Yang Layak. (AAUPL) di Lingkungan Peradilan Administrasi di Indonesia (Upaya Menuju "Clean and Stable Government"), Citra Aditya Bakti, Bandung, 1999, hlm. 33.

${ }^{19}$ Ibid.

${ }^{20}$ Ibid., hlm. 34 
juga tergantung pada kemampuan ilmu pengetahuan, pengalaman dan kepemimpinan. Wewenang berfungsi untuk menjalankan kegiatan yang ada dalam organisasi. ${ }^{21}$ Pengorganisasian (Organizing) merupakan proses penyusunan struktur organisasi yang sesuai dengan tujuan organisasi, sumber daya-sumber daya yang dimilikinya dan lingkungan yang melingkupinya. ${ }^{22}$

Menurut Hani Handoko ada dua pandangan yang saling berlawanan mengenai sumber wewenang: a) Teori Formal (pandangan klasik) adalah wewenang dianugerahkan, yakni wewenang ada karena seseorang diberikan atau dilimpahkan hal tersebut. b) Teori Penerimaan (acceptance theory of authority) adalah berpendapat bahwa wewenang seseorang timbul hanya apabila hal itu diterima oleh kelompok atau individu kepada siapa wewenang tersebut dijalankan dan ini tidak tergantung pada penerima (reciver). ${ }^{23}$

Kewenangan diperoleh oleh seseorang melalui 2 cara yaitu dengan atribusi atau dengan pelimpahan wewenang (delegasi). ${ }^{24}$ Pada atribusi terjadi pemberian wewenang pemerintahan yang baru oleh suatu ketentuan perundang-undangan, sedangkan dalam delegasi terjadi pelimpahan wewenang yang telah ada oleh Badan yang telah memperoleh suatu wewenang pemerintahan secara atributif kepada badan atau pejabat pemerintahan lainnya. Pada atribusi maupun delegasi, adapun pihak yang bertanggung jawab kepada pelaksanaan tugas bersangkutan dibebankan kepada penerima kewenangan. ${ }^{25}$

Merujuk pada tatanan konsep di atas, maka dalam kaitannya wewenang pejabat publik dalam menerbitkan suatu kebijakan merupakan atribusi dari undang-undang, dalam hal ini yaitu Undang-Undang No. 30 Tahun 2014 tentang Administrasi Pemerintahan. Pasal 1 angka 1 menyebutkan bahwa: "Administrasi Pemerintahan adalah tata laksana dalam pengambilan keputusan dan/atau tindakan oleh badan dan/atau pejabat pemerintahan". Berdasarkan Kamus Besar Bahasa Indonesia, secara terminologi bahasa menjelaskan tata laksana mempunyai

${ }^{21}$ S.F. Marbun, Pembentukan, Pemberlakuan, Dan Peranan Asas-asas Umum Pemerintahan yang Layak dalam Menjelmakan Pemerintahan Yang Baik dan Bersih di Indonesia, Disertasi, Universitas Padjajaran Bandung, 2001, hlm. 44

22 R. Sri Soemantri M., Bunga Rampai Hukum Tata Negara Indonesia, Alumni, Bandung, 1992, hlm. 29

${ }^{23}$ Moh. Mahfud MD, Politik. Hukum di Indonesia, Pustaka LP3ES, Jakarta, 1998, hlm. 376

${ }^{24}$ R. Sri Soemantri M., Loc., Cit.

${ }^{25}$ Ibid. 
pengertian: "cara mengurus (menjalankan) perusahaan/organisasi dan sebagainya". 26

Mengutip pendapat Thomas R. Dye menyebutkan bahwa kebijakan publik dikatakan sebagai apa yang tidak dilakukan maupun apa yang dilakukan oleh pemerintah. Definisi kebijakan publik menurut Thomas R. Dye ini dapat diklasifikasikan sebagai keputusan (decision making), di mana pemerintah mempunyai wewenang untuk menggunakan keputusan otoritatif, termasuk keputusan untuk membiarkan sesuatu terjadi, demi teratasinya suatu persoalan publik. ${ }^{27}$

Berdasarkan pendapat di atas, dipahami bahwa diskresi merupakan wewenang pejabat publik yang dimiliki berdasarkan undang-undang. Di mana kebijakan dimaksud ditetapkan berdasarkan kepentingan umum dan atas dasar belum ditetapkannya suatu payung hukum untuk menjalankan suatu kegiatan pemerintahan.

\section{Re-orientasi Penetapan Diskresi Pasca Putusan Mahkamah Konstitusi}

Pola Pertanggungjawaban Yang Harus Dilakukan Pejabat Pemerintahan Setelah Menetapkan Diskresi

Pejabat negara adalah pejabat yang lingkungan kerjanya berada pada lembaga negara yang merupakan alat kelengkapan negara beserta derivatifnya berupa lembaga negara pendukung. ${ }^{28}$ Spesifikasi jabatan (job specification) menunjukkan siapa yang melakukan pekerjaan itu dan faktor-faktor manusia yang diisyaratkan. Di dalam spesifikasi jabatan ditentukan kemampuan dan bakat dasar yang harus dimiliki untuk menjalankan pekerjaan. Pada umumnya spesifikasi jabatan memuat ringkasan pekerjaan yang jelas yang diikuti oleh kualifikasi definitif yang dibutuhkan dari calon yang memangku jabatan itu. Spesifikasi jabatan adalah persyaratan minimal yang harus dipenuhi oleh orang yang menduduki suatu jabatan, agar dapat melaksanakan tugas yang dibebankan kepadanya dengan baik dan bertanggung jawab. ${ }^{29}$

${ }^{26}$ http:/ / kbbi.web.id/tata\%20laksana, diakses tanggal 13 Juni 2017

${ }^{27}$ Thomas R. Dye, Understanding Public Policy, USA: Prentice-Hall, INC., Englewood Cliffs, NJ, 1992, hlm.87.

${ }^{28}$ Firmansyah Arifin et., al., Lembaga Negara dan Sengketa Antar Lembaga Negara, Konsorsium Reformasi Hukum Nasional (KRHN) Bekerjasama Dengan Mahkamah Konstitusi RI, Jakarta, 2005, hlm. 43

${ }^{29}$ Julista Mustamu,"Diskresi Dan Tanggungjawab Administrasi Pemerintahan”, Jurnal Sasi Vol. 17 No. 2 Bulan April-Juni 2011, hlm. 1 
Etika pejabat negara dalam penyelenggaraan pemerintahan yang bersih mempunyai kedudukan yang penting. Sebagai pedoman moral dalam menyelenggarakan tertib pemerintahan, maka, etika pejabat negara menjadi rujukan dalam berperilaku sehingga upaya menciptakan pemerintahan yang bersih pun akan lebih mudah tercapai. Sebaliknya, pelanggaran terhadap etika tersebut akan memunculkan perilaku buruk bahkan dapat menyebabkan terjadinya pelanggaran pidana. ${ }^{30}$

Merujuk pada pemaparan di atas, menarik disimak terkait Putusan MK No. 25/PUU-XIV/2016 tentang pengujian Undang-Undang No. 31 Tahun 1999 dan Undang-Undang No. 20 Tahun 2001 terkait penetapan diskresi yang dilakukan oleh kepala daerah. Dalam menjalankan setiap program pemerintahannya, kepala daerah dapat menetapkan diskresi khususnya terkait penggunaan anggaran sepanjang belum adanya payung hukum yang mengatur.

Mahkamah Konstitusi dalam putusannya mengutip pengertian “dapat” yang menjadi objek permasalahan dalam judicial review undang-undang tindak pidana korupsi. Menurut Mahkamah Konstitusi kata "dapat" bermakna "mampu". "sanggup", "bisa”, "boleh", serta "mungkin". Maka kata "dapat” tidak memiliki makna yang pasti. Rumusan frasa "dapat" merugikan keuangan atau perekonomian negara sebagaimana disebutkan dalam Pasal 2 ayat (1) dan Pasal 3 bisa bermakna: merugikan keuangan negara, mungkin merugikan keuangan negara, potensial merugikan keuangan negara, serta tidak harus merugikan keuangan negara yang nyata. ${ }^{31}$ Atas dasar tersebut maka MK menyatakan bahwa kata "dapat" bersifat inkonstitusional karena mengandung ketidakpastian hukum dan ketidakadilan. Hal tersebut telah diuraikan dalam beberapa yurisprudensi putusan MK sebelumnya.

Pada pertimbangan putusan tersebut, Mahkamah Konstitusi menyatakan bahwa Undang-Undang No. 30 Tahun 2014 tentang Administrasi Pemerintahan yang dikaitkan dengan frasa kata "dapat" dalam undang-undang tindak pidana

30 M. Nasir Djamil dan TB Massa Djafar, "Etika Publik Pejabat Negara dalam Penyelenggaraan Pemerintahan yang Bersih”, Jurnal Politik, Vol. 12 No. 01, 2016, hlm. 1758

${ }^{31}$ Lihat Putusan Mahkamah Konstitusi No. 25/PUU-XIV/2016, hlm. 95 
korupsi menyebabkan terjadinya pergeseran paradigma penerapan unsur merugikan keuangan negara dalam tindak pidana korupsi. ${ }^{32}$

Pencantuman kata "dapat" dalam undang-undang tindak pidana korupsi membuat delik korupsi menjadi delik formil. Sehingga menurut Mahkamah Konstitusi, dalam prakteknya sering disalahgunakan guna menjangkau perbuatan yang diduga merugikan keuangan negara. Termasuk dalam hal pelaksanaan diskresi/freies Ermessen yang diambil oleh pejabat bersifat mendesak dan belum ditentukan dasar hukumnya, sehingga sering terjadinya kriminalisasi dengan dugaan penyalahgunaan wewenang. Maka menurut Mahkamah Konstitusi dalam pertimbangan hukumnya Pasal 2 ayat (1) dan Pasal 3 Undang-Undang Tindak Pidana Korupsi bertentangan dengan perumusan tindak pidana yang harus memenuhi prinsip hukum tertulis (lex scripta), harus ditafsirkan seperti yang dibaca (lex stricta) dan tidak multitafsir (lex certa). ${ }^{33}$ Amar putusan Mahkamah Konstitusi memutuskan bahwa menyatakan kata "dapat" dalam Pasal 2 ayat (1) dan Pasal 3 Undang-Undang No. 31 Tahun 1999 dan Undang-Undang No. 20 Tahun 2001 tentang Tindak Pidana Korupsi bertentangan dengan UUD NRI Tahun 1945 dan tidak mempunyai kekuatan hukum mengikat. ${ }^{34}$

Berdasarkan amar putusan yang telah ditetapkan dalam Putusan No. 25/PUU-XIV/2016, maka seyogyanya pejabat pemerintahan yang hendak menjalankan programnya serta diketengahi dengan penggunaan anggaran baik anggaran negara maupun daerah dapat menetapkan diskresi sebagaimana mestinya tanpa timbulnya kekhawatiran akan terjerat tindak pidana korupsi. ${ }^{35}$

Dalam kebijakan selalu terkait dengan pertanggungjawaban yaitu pertanggungjawaban moral atau pertanggungjawaban hukum atau kedua-duanya, yang idealnya ialah bahwa kebijakan itu dapat dipertanggungjawabkan baik secara moral maupun secara hukum. Prinsip dari negara hukum adalah asas legalitas yang mengandung pengertian bahwa setiap tindakan hukum pemerintah harus berdasarkan pada peraturan perundang-undangan yang berlaku atau setiap

\footnotetext{
32 Lihat Putusan Mahkamah Konstitusi No. 25/PUU-XIV/2016, hlm. 112

${ }^{33}$ Lihat Putusan Mahkamah Konstitusi No. 25/PUU-XIV/2016, hlm. 113-114

${ }^{34}$ Lihat Putusan Mahkamah Konstitusi No. 25/PUU-XIV/2016, hlm. 116

35 Anonimous, Hukum Acara Mabkamah Konstitusi, Sekretaris Jenderal dan Kepaniteraan Mahkamah Konstitusi RI BekerjasamadenganAsosiasi Pengajar Hukum Acara Mahkamah Konstitusi, Jakarta, 2010, hlm. 53
} 
tindakan hukum pemerintahan harus berdasarkan kewenangan yang diberikan oleh perundang-undangan. Kebijakan pemerintah dalam rangka mewujudkan good governance harus berlandasan tanggung jawab dari pemerintah. Tanggung jawab pemerintah dalam hal ini adalah tanggung jawab moral dan tanggung jawab hukum. Tanggung jawab pemerintah adalah kewajiban penataan hukum dari negara atau pemerintah atau pejabat pemerintah atau pejabat lain. ${ }^{36}$

Pertanggungjawaban pemerintah muncul karena ada 2 hal yaitu adanya kewenangan dan adanya hak dan kewajiban. Kewenangan hak dan kewajiban tersebut merupakan perbuatan pemerintah yang harus dipertanggungjawabkan. Pemerintah merupakan pihak yang paling bertanggug jawab atas kesejahteraan warga negara dan untuk mewujudkan ini pemerintah diberi wewenang untuk campur tangan dalam kehidupan masyarakat, yang di dalam campur tangan ini tidak saja berdasarkan pada peraturan perundang-undangan tetapi dalam keadaan dapat bertindak tanpa bersandar pada peraturan perundang-undangan tetapi berdasarkan inisiatif yaitu kebijakan dalam mewujudkan pemerintahan yang baik. ${ }^{37}$

Adapun bentuk pertanggungjawaban pemerintah terkait keuangan yakni Undang-Undang No. 17 Tahun 2003 tentang Keuangan Negara, khususnya Pasal 30-32 menjelaskan tentang bentuk pertanggungjawaban keuangan negara. Dalam hal tersebut baik Presiden maupun Kepala Daerah (Gubernur, Bupati, Walikota) diwajibkan untuk menyampaikan pertanggungjawaban pelaksanaan APBN/APBD kepada DPR/DPRD berupa laporan keuangan yang telah diperiksa BPK selambat-lambatnya 6 bulan setelah tahun anggaran berakhir.

Berdasarkan tujuan dan lingkup pertanggung jawaban yang telah dipaparkan di atas, maka pola pertanggung jawaban pemerintah dalam pengelolaan keuangan negara maupun daerah setelah menerbitkan diskresi/kebijakan pelaksanaan suatu program dapat membuat laporan keuangan dan berkordinasi dengan BPK untuk melakukan audit keuangan yang telah digunakan kepada DPRD. Dengan adanya pola kordinasi tersebut maka pejabat pemerintah dalam mengelola keuangan

\footnotetext{
36 Alent R. Tumengkol, "Kebijakan Pemerintah Dan Pertanggungjawabannya Dalam Rangka Good Governance", Jurnal Lex Administratum, Vol. III/No.1/Jan-Mar/2015, hlm. 112

${ }^{37}$ Ibid.
} 
negara maupun daerah dapat terhindar dari penyalahgunaan wewenang dan dapat diterapkannya asas transparansi kepada publik agar publik mengetahui arah penggunaan anggaran yang telah dibelanjakan oleh setiap pejabat pemerintahan.

\section{Batasan dan Upaya Pencegahan yang Harus Dilakukan Oleh Pejabat Pemerintahan dalam Menerbitkan Diskresi Agar Terhindar dari Tindak Pidana Korupsi}

Keberadaan hukum administrasi merupakan kontrol terhadap begitu luasnya campur tangan pemerintah dalam berbagai aspek kehidupan. Oleh karenanya produk regulasi tidak hanya untuk masyarakat, melainkan juga untuk mengatur dan membatasi aparatur pemerintah seperti istilah the juridical task of criminal is not policing society, but policing the police.38 Dalam realitasnya pelaksanaan pemerintahan tidak hanya berlandaskan pada perundang-undangan, tetapi juga berdasarkan pada inisiatif publik. Adanya kebebasan kebijakan baik dalam bentuk keputusan maupun tindakan pejabat administratif (perbuatan Pejabat Pemerintahan) atau penyelenggara negara lainnya untuk melakukan tindakan dan/atau tidak melakukan perbuatan konkret dalam rangka penyelenggaraan pemerintahan Pasal 1 angka 8 UU No. 30 Tahun 2014 tentang Administrasi Pemerintahan melalui freies Ermessen atau hak khusus seseorang untuk menilai dan mempertimbangkan ketika mengambil suatu kebijakan dengan mengutamakan tercapainya tujuan yang dicita-citakan oleh ketentuan hukum normatif itu sendiri.

Kebebasan kebijakan pejabat pemerintahan disamakan dengan pengertian diskresi, yang menurut Pasal 1 angka 9 UU No. 30 Tahun 2014 tentang Administrasi Pemerintahan dinyatakan sebagai suatu keputusan dan/atau tindakan yang ditetapkan dan/atau dilakukan oleh Pejabat Pemerintahan untuk mengatasi persoalan konkret yang dihadapi dalam penyelenggaraan pemerintahan dalam hal peraturan perundangan-undangan yang memberikan pilihan, tidak mengatur, tidak lengkap atau tidak jelas, dan/atau adanya stagnasi pemerintahan.

Lebih lanjut berdasarkan UU No. 30 Tahun 2014 tentang Administrasi Pemerintahan menyebutkan bahwa Pejabat Pemerintahan yang menggunakan diskresi harus memenuhi syarat: 1) Sesuai dengan tujuan diskresi sebagaimana dimaksud dalam Pasal 22 ayat (2); 2) Tidak bertentangan dengan ketentuan 
peraturan perundang-undangan; 3) Sesuai dengan AUPB; 4) Berdasarkan alasanalasan yang objektif; 5) Tidak menimbulkan konflik kepentingan; 6) Dilakukan dengan itikad yag baik (Pasal 24 UU AP).

Pejabat Pemerintahan yang menggunakan Diskresi harus memenuhi syarat: 1) Sesuai dengan tujuan diskresi sebagaimana dimaksud dalam Pasal 22 ayat (2); 2) Tidak bertentangan dengan ketentuan peraturan perundang-undangan; 3) Sesuai dengan asas umum pemerintahan yang baik (AUPB); 4) Berdasarkan alasan-alasan yang objektif; 5) Tidak menimbulkan konflik kepentingan; dan dilakukan dengan iktikan baik. 39

Ketaat-asasan itu pada hakikatnya mengandung dua hal, yaitu: 1) Manakala Pemerintah (pusat atau daerah tingkat atasnya) sudah mengadakan peraturan penyelenggaran pemerintahan, maka daerah tidak boleh mengaturnya; 2) Apabila sebaliknya, maka pemerintah (pusat atau daerah tingkat atasnya) dapat mengatur kembali penyelenggaran pemerintahan yang telah diatur daerah, terkecuali bilamana dinyatakan dengan tegas oleh undang-undang. ${ }^{40}$

Titik terang dalam pelaksanaan diskresi pejabat pemerintah adalah apakah terdapat penyalahgunaan kewenangan yang menjadi kewenangan tata usaha negara, yang meliputi, apakah pejabat pemerintahan telah menjalankan wewenang berdasarkan peraturan perundang-undangan yang berlaku dan apakah pejabat pemerintahan telah menerapkan asas-asas umum pemerintahan yang baik dalam menjalankan kewenangannya tersebut.

Maka, diskresi bukan berarti kesewenangan pejabat pemerintahan dalam bertindak untuk mencapai tujuan dan cita-cita pemerintah yang dipimpinnya. Namun ada hak dan kewajiban yang menjadi batas dan ukuran penilaian yang objektif. Sehingga asas-asas umum pemerintahan yang baik sebagai acuan pejabat pemerintahan dalam mengeluarakan keptusan dan/atau tindakan dalam penyelenggaraan pemerintahan dapat dinilai baik akuntabilitasnya oleh masyarakat dan memberikan kemaslahatan bagi rakyat yang dipimpin.

\footnotetext{
39 Ratna Nurhayatidan Seno Wibowo Gumbira, "Pertanggungjawaban Publik Dan Tindak Pidana Korupsi”, Jurnal Hukum dan Peradilan, Vol. 6, No. 1, Maret 2017, hlm. 54

${ }^{40}$ Ibid., hlm. 52
} 
Selanjutnya terkait upaya pencegahannya dapat dilihat bahwa hukum administrasi menempati posisi dominan dalam penanganan tindak pidana korupsi, baik preventif berupa pencegahan tindak pidana korupsi maupun represif yaitu penanganan/penindakan tindak pidana korupsi. Dari sisi preventif, hukum administrasi merupakan instrumen hukum utama berkaitan dengan tiga dimensi hukum administrasi yaitu norma untuk, oleh dan terhadap pemerintah. Dari sisi represif, hukum administrasi sangat dominan karena tipikor hanya mungkin terjadi dalam konteks kerugian keuangan negara yang diakibatkan oleh maladministrasi yang paling utama adalah penyalahgunaan wewenang. ${ }^{41}$

Apabila ditinjau dari segi doktrin, penyalahgunaan wewenang dalam konsep hukum administrasi selalu diparalelkan dengan konsep detournement de pouvoir (penggunaan wewenang tidak sebagaimana mestinya). Dalam hal ini pejabat menggunakan wewenangnya untuk tujuan lain yang menyimpang dari tujuan yang telah diberikan kepada wewenang itu. Dengan demikian pejabat melanggar asas spesialitas. ${ }^{42}$

Menarik disimak pendapat dari Romli Atmasasmita menyebutkan penyalahgunaan wewenang baik dalam UU Administrasi Negara dan UU Tipikor perlu dibedakan. Dengan adanya perkembangan saat ini yakni dengan adanya Judicial Review Putusan Mahkamah Konstitusi No. 25/PUU-XIV/2016, yang menyatakan penegak hukum harus membuktikan adanya kerugian negara sebagaimana yang terdapat dalam Pasal 2 ayat (1) dan Pasal 3 UU Tipikor. Sehingga kerugian negara dalam perkara korupsi tidak bisa lagi bersifat potensi (potential loss). ${ }^{43}$

Putusan Mahkamah Konstitusi dalam pertimbangannya menyebutkan "Pencantuman kata "dapat" membuat delik dalam Pasal 2 ayat (1) dan Pasal 3 menjadi delik formil. Pada praktiknya, delik ini sering disalahgunakan untuk memidanakan kebijakan atau keputusan diskresi yang diambil karena mendesak dan tidak memiliki landasan hukum. Kriminalisasi kebijakan terjadi karena

41 Philipus M. Hadjon, “Kisi-Kisi Hukum Administrasi Dalam Konteks Tindak Pidana Korupsi,” dalam Hukum Administrasi Dan Tindak Pidana Korupsi, Gajah Mada University Press, Jogjakarta, 2011, hlm. 2

${ }^{42}$ Ibid., hlm. 20

${ }^{43}$ Romli Atmasasmita, "Pencegahan Dan Pemberantasan Korupsi Dalam Tugas Kedinasan (Pasca UU No. 30 Tabun 2014)" in OC. Kaligis, Alumni, Bandung, 2015, hlm. 92 
terdapat perbedaan pemaknaan kata "dapat" dalam unsur kerugian negara dan keberadaan UU Administrasi Pemerintahan, paradigma penerapan unsur merugikan keuangan negara dalam tindak pidana korupsi telah bergeser. ${ }^{44}$

Menyimpulkan dari pendapat Romli Atmasasmita di atas, bahwa putusan MK No. 25/PUU-XIV/ 2016 telah memberikan ruang gerak yang luas bagi pejabat publik dalam menerbitkan suatu diskresi. Keleluasan yang dimaksud bukan bermakna tanpa adanya batasan dan dapat memungkinkan terjadinya penyalahgunaan wewenang.

Oleh karena itu, tepat kiranya setiap pejabat pemerintahan yang telah menerbitkan diskresi dapat memberikan laporan keuangannya baik kepada parlemen daerah maupun kepada publik sebagai bagian asas transparansi dan akuntabilitas. Hal tersebut merupakan manifestasi dari asas-asas umum pemerintahan yang baik (AUPB).

\section{Penutup}

Pola pertanggungjawaban atas ditetapkannya diskresi oleh pejabat pemerintahan terkait keuangan negara dilakukan dengan menyampaikan laporan kepada lembaga legislatif baik tingkat pusat maupun daerah sebagaimana dimaksudkan dalam Asas-asas Umum Pemerintahan Yang Baik dan Bersih (AUPB) berdasarkan Undang-Undang No. 30 Tahun 2014 tentang Administrasi Pemerintahan. Polanya selain dilaporkan kepada lembaga legislatif selaku pengawas juga dapat berkordinasi dengan BPK dalam melakukan audit keuangan. Dengan adanya pola demikian maka diyakini bahwa setiap pejabat pemerintahan yang akan menerbitkan suatu diskresi atas penggunaan anggaran negara maupun daerah dapat diberdayakan sesuai kebutuhan dan sebagaimana mestinya. Sehingga lembaga lainnya dapat mengontrol tindakan pejabat pemerintah yang menerbitkan diskresi agar tidak melakukan perbuatan penyalahgunaan kewenangan.

Adapun batasan bagi pejabat pemerintahan dalam menerbitkan diskresi khususnya pasca Putusan Mahkamah Konstitusi yaitu dengan ketaat asasan pada ketentuan peraturan perundang-undangan. Di mana pejabat pemerintah wajib 
memperhatikan regulasi/diskresi yang telah ditetapkan oleh pejabat atasannya sehingga asas peraturan yang tingkat derajatnya rendah tidak boleh bertentangan dengan peraturan yang tingkat derajatnya lebih tinggi benar-benar diperhatikan. Sehingga pejabat pemerintahan telah menerapkan asas-asas umum pemerintahan yang baik dalam menjalankan kewenangannya tersebut. Dalam hal upaya pencegahan dari tindak pidana korupsi, maka setiap pejabat pemerintahan wajib melaporkan pengelolaan anggaran yang telah digunakan berdasarkan diskresi yang telah ditetapkannya sehingga asas transparansi dan akuntabilitas menurut AUPB terealisasi dengan baik.

\section{Daftar Pustaka}

\section{Buku}

Anonimous, Hukum Acara Mahkamah Konstitusi, Sekretaris Jenderal dan Kepaniteraan Mahkamah Konstitusi RI Bekerjasama dengan Asosiasi Pengajar Hukum Acara Mahkamah Konstitusi, Jakarta, 2010.

Anderson, James E., Public Policy Making, cet. ke-3, Holt, Rinehart and Winston, New York, 1984.

Arifin, Firmansyah, et., al., Lembaga Negara dan Sengketa Antar Lembaga Negara, Konsorsium Reformasi Hukum Nasional (KRHN) Bekerjasama Dengan Mahkamah Konstitusi RI, Jakarta, 2005.

Atmasasmita, Romli, "Pencegahan Dan Pemberantasan Korupsi Dalam Tugas Kedinasan (Pasca UU No 30 Tahun 2014)" in OC. Kaligis, Alumni, Bandung, 2015.

Dye, Thomas R., Understanding Public Policy, USA: Prentice-Hall, INC., Englewood Cliffs, NJ, 1992.

Hamidi, Jazim, Penerapan Asas-asas Umum Penyelenggaraan Pemerintahan Yang Layak (AAUPL) dilingkungan Peradilan administrasi di Indonesia (Upaya Menuju "Clean and Stable Government"), Citra Aditya Bakti, Bandung, 1999.

Hadjon, Philipus M., “Kisi-Kisi Hukum Administrasi Dalam Konteks Tindak Pidana Korupsi," dalam Hukum Administrasi Dan Tindak Pidana Korupsi, Gajah Mada University Press, Jogjakarta, 2011.

HR, Ridwan, Hukum Administrasi Negara, PT. Raja Grafindo Persada, Jakarta, 2007. Islamy, Irfan M., Prinsip-Prinsip Perumusan Kebijakan Negara, Cet. ke-15, Bumi Aksara, Jakarta, 2009.

Mahfud MD., Moh., Politik Hukum di Indonesia, Pustaka LP3ES, Jakarta, 1998.

Marbun, S.F., Peradilan Administrasi Negara dan Upaya Administratif di Indonesia, FH UII Press, Yogyakarta, 2011. 
Marzuki, Peter Mahmud, Penelitian Hukum, Kencana Prenada Media Group, Jakarta, 2005.

Mulyosudarmo, Suwoto, Kekuasaan dan Tanggung Jawab Presiden Republik Indonesia, Suatu Penelitian Segi-Segi Teoritik dan Yuridis Pertanggungjawaban Kekuasaan, Universitas Airlangga, Surabaya, 1990.

Saputra, Nata, Hukum Administrasi Negara, Rajawali, Jakarta, 1988.

Sri Soemantri M., R., Bunga Rampai Hukum Tata Negara Indonesia, Alumni, Bandung, 1992.

\section{Hasil Penelitian}

Marbun, S.F., “Pembentukan, Pemberlakuan, Dan Peranan Asas-asas Umum Pemerintahan yang Layak dalam Menjelmakan Pemerintahan Yang Baik dan Bersih di Indonesia", Disertasi, Universitas Padjajaran Bandung, 2001.

\section{Jurnal}

Muhlizi, Arfan Faiz, "Reformulasi Diskresi Dalam Penataan Hukum Administrasi”, Jurnal Rechtsvinding, Vol. 1 No. 1, Januari-April 2012.

Mustamu, Julista, "Diskresi Dan Tanggungjawab Administrasi Pemerintahan”, Jurnal Sasi Vol. 17 No. 2 Bulan April-Juni 2011.

Nasir Djamil M., dan TB Massa Djafar, “Etika Publik Pejabat Negara dalam Penyelenggaraan Pemerintahan yang Bersih", Jurnal Politik, Vol. 12 No. 01, 2016.

Ratna Nurhayatidan Seno Wibowo Gumbira, "Pertanggungjawaban Publik Dan Tindak Pidana Korupsi", Jurnal Hukum dan Peradilan, Vol. 6, No. 1, Maret 2017.

Tumengkol, Alent R., “Kebijakan Pemerintah Dan Pertanggung jawabannya Dalam Rangka Good Governance", Jurnal Lex Administratum, Vol. III/No.1/JanMar/2015.

\section{Kamus}

Anonimous, Penyusunan Kamus Hukum Umum Bahasa Belanda-Bahasa Indonesia, BPHN Departemen Kehakiman, Jakarta, 1999.

, Kamus Besar Bahasa Indonesia, Pusat Bahasa Departemen Pendidikan Nasional Jakarta, 2008.

\section{Internet}

"332 Pejabat Terjerat Korupsi, Negara Rugi Rp 39,3Triliun", http://kpk.go.id/ id/nukpk/id/berita/berita-sub/726-332-pejabat-terjerat-korupsi-negara-rugi-rp39-3-triliun, diaksespadatanggal 13 Juni 2017.

http://kbbi.web.id/tata\% 20laksana, diakses tanggal 13 Juni 2017. 


\section{Majalah}

Anwar Usman dalam Laporan Utama, "Potensi Kriminalisasi, Kata “dapat” Dalam UU Tipikor Inkonstitutional”, Majalah Konstitusi No. 120, Edisi Februari 2017.

\section{Peraturan Perundang-Undangan}

Undang-Undang Dasar Negara Republik Indonesia Tahun 1945.

Undang-Undang Nomor 31 Tahun 1999 tentang Pemberantasan Tindak Pidana Korupsi (Lembaran Negara Republik Indonesia Tahun 1999 Nomor 140, Tambahan Lembaran Negara Republik Indonesia Nomor 387).

Undang-Undang Nomor 21 Tahun 2001 tentang Perubahan Atas Undang-Undang Nomor 31 Tahun 1999 tentang Pemberantasan TindakPidana Korupsi (Lembaran Negara Republik Indonesia Tahun 2001 Nomor 134, Tambahan Lembaran Negara Republik Indonesia Nomor 4150).

Undang-Undang Nomor 17 Tahun 2003 tentang Keuangan Negara (Lembaran Negara Republik Indonesia Tahun 2003 Nomor 47, Tambahan Lembaran Negara Republik Indonesia Nomor 4286).

Undang-Undang Nomor 30 Tahun 2014 tentang Administrasi Pemerintahan (Lembaran Negara Republik Indonesia Tahun 2014 Nomor 292, Tambahan Lembaran Negara Republik Indonesia Nomor 5601).

Putusan Mahkamah Konstitusi No. 25/PUU-XIV/2016 mengenai pengujian Undang-Undang No 31/1999 tentang Pemberantasan Tidak Pidana Korupsi juncto UU No 20/2001 tentang Perubahan atas UU No 31/1999 tentang Pemberantasan Tindak Pidana Korupsi. 